\title{
IMPROVEMENT OF THE SEED METERING DEVICE OF POWER TILLER OPERATED ZERO TILL DRILL
}

\author{
M. S. Hossen, A. A. Musabbir, M. M. Hossain'1, M. Z. Hasan and M. A. Islam \\ Department of Farm Power and Machinery, Bangladesh Agricultural University, \\ Mymensingh-2202, Bangladesh
}

\begin{abstract}
This study was carried out in wheat research center, BARI under financial assistance of CIMMYT for the improvement of seed metering device of a power tiller operated zero till drill planter. Fluted roller type seed metering device was replaced by the inclined plate type seed metering device. Field experiments revealed that field efficiency was $80.19 \%$ and seed damage was completely absent in the improved metering device. Further cost analysis showed saving of 280 Taka ha ${ }^{-1}$ planting cost, which proves success of the improvement.
\end{abstract}

Key Words: Zero tillage, Seed drill, Inclined plate type, Fluted roller type, Metering device

\section{INTRODUCTION}

Zero tillage is defined as the planting of crops in previously unprepared soil by opening a narrow slot, trench, or band only of sufficient width and depth to obtain proper seed coverage. No other soil preparation is performed (Phillips and Young, 1973). Over the past years, various agronomic management systems have been proposed and tested that preserve or improve soil quality. One of these systems is conservation agriculture. Conservation agriculture is defined as any management system that includes the following characteristics (Wall, 2006): first, a serious reduction in soil movement with the ultimate goal to eliminate it completely except for the disturbance caused when sowing, i.e. zero tillage; second, the preservation of a permanent or semi permanent organic cover, i.e. standing crop or a layer of stubble, on the soil and third, the rotation of economically viable crops. Conservation agriculture based technologies reduce water and wind erosion by approximately 50\%, in contrast to conventional tillage (Figueroa and Morales, 1992). In the past, conservation tillage was based on the use of human and animal force and manure. Since the second half of the 20th century, it has resorted mostly to the use of agricultural machinery and chemicals to achieve yield increase. Although conservation tillage resulted in yield increments, yet soils subjected to conservation tillage for a long time can be negatively affected in terms of their physical, chemical and biological conditions, with the consequence that they cannot sustain their historical level of production. Consequently, larger amounts of fertilizers are applied with use of more machinery to simply maintain yields as the production system is no longer sustainable and the soil quality is reduced

1Professor, Department of Farm Power and Machinery, Bangladesh Agricultural University, Mymensingh-2202, Bangladesh 
(Lampkin, 1998). Water is the primary constraint to crop production in semi-arid regions. Approximately $40 \%$ (600Mha) of the world's cropland area is affected by low and unpredictable rainfall, with $60 \%$ of these lands located in developing countries (Johnston et al., 2002). Zero tillage combined with crop residue retention on the soil surface, can improve moisture infiltration, and greatly reduce erosion and enhance water use efficiency compared to conservation tillage (Johnston et al., 2002; Shaver et al., 2002). Crop residue on the soil surface forms a barrier to water loss by evaporation, increasing the amount of moisture stored in the plant root zone and available to the crop. Field research has shown higher moisture levels, decreased soil temperatures and also more stable soil aggregates, i.e. improved soil structure, under zero tillage compared to conservation tillage (Carter, 1992; Lichter et al., 2008).

Zero till drill is a unique, economical and useful machine, which is used to sow the crop directly without tillage operations. It saves time, fuel and considerable cost as compared to conventional practices, which is a major part of expenditures in farming. Different types of seed metering devices are used for seeding different cereal crops. Fluted roller type seed metering device was used for sowing paddy seeds, cup filled type seed metering device was used for sowing mungbean seeds in the previous version of the zero till drill. Inclined plate type seed metering device is of another type which has been developed to reduce seed damage and to maintain uniform seed to seed distance. Keeping the aforementioned facts in mind, this study was conducted to compare planting performance and cost of the inclined plate type seed metering device with those of the fluted roller type seed metering device.

\section{MATERIALS AND METHODS}

A power tiller operated zero till drill was procured and studied to fulfill the specific objectives of the experiment. Specifications of the zero till drill are presented in Table 1.

Table 1. Specifications of the Power tiller operated zero till drill

\begin{tabular}{lc|l|l}
\hline \multicolumn{1}{c}{ Components } & No. & \multicolumn{1}{c}{ Dimension/Type } & Material(s) \\
\hline Toolbar frame $(\mathrm{L} \times \mathrm{W})$ & 1 & $94 \mathrm{~cm} \times 77.5 \mathrm{~cm}$ & MS bar \\
Seed box $(\mathrm{L} \times \mathrm{W} \times \mathrm{H})$ & 2 & $81 \mathrm{~cm} \times 21 \mathrm{~cm} \times 18 \mathrm{~cm}$ & Plain sheet \\
Fertilizer box $(\mathrm{L} \times \mathrm{W} \times \mathrm{H})$ & 2 & $85 \mathrm{~cm} \times 24 \mathrm{~cm} \times 16 \mathrm{~cm}$ & Plain sheet \\
Seed tube $(\mathrm{L} \times \mathrm{W} \times \mathrm{H})$ & 4 & $10 \mathrm{~cm} \times 17 \mathrm{~cm} \times 9 \mathrm{~cm}$ & Plastic sheet \\
Furrow opener $(\mathrm{L} \times \mathrm{W})$ & 4 & $23.3 \mathrm{~cm} \times 12.3 \mathrm{~cm}$ & Heavy flat bar \\
Depth Control devices & 2 & & MS bar \\
Seed metering devices & 3 & Inclined type & Aluminium and plastic \\
\hline Power transmission system & & & Material(s) \\
\hline Attached tractor & & Power tiller $12 \mathrm{HP}$ Dongfeng hand 2-wheel tractor \\
\hline Components & No. & Description & Roller chain \\
\hline Chain & 1 & Roller-420 & Steel \\
Sprocket & 2 & $22 \& 19$ teeth & MS iron \\
Clutch & 1 & Dog clutch &
\end{tabular}




\section{Improvement of the seed metering device}

Fluted roller type seed metering device was used in the previous version of zero till drill which caused seed damage during operation.
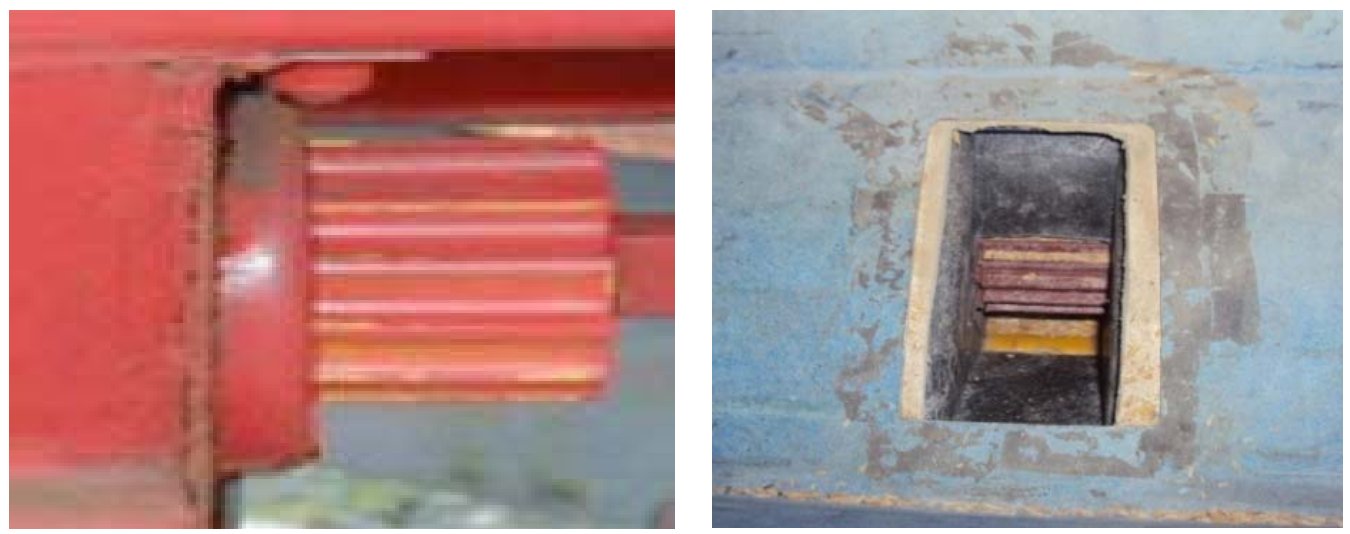

Fig. 1. Fluted wheel type seed metering device

Dabbaghi et al. (2010) reported that the damaged seeds increased with increasing metering device rotational speed. So the fluted roller type was replaced by inclined plate type seed metering device to eliminate seed damage in the present version of zero till drill.

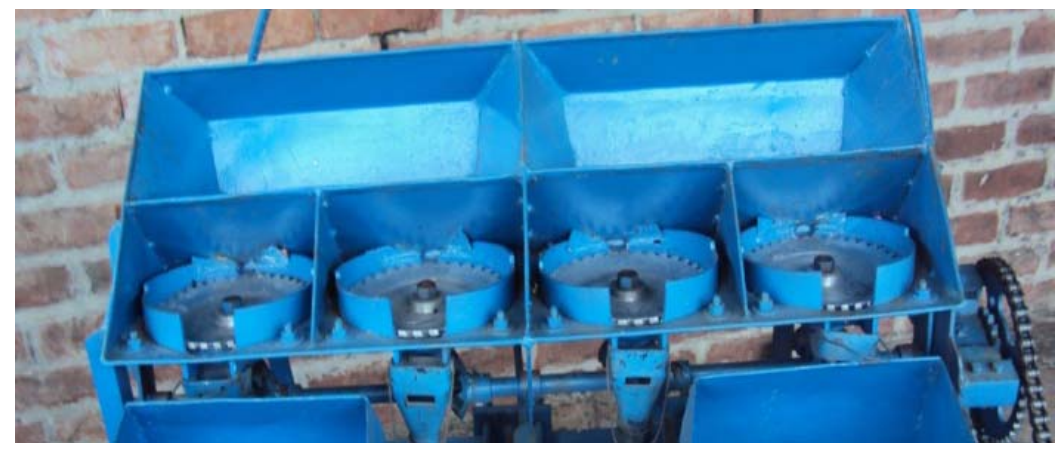

a

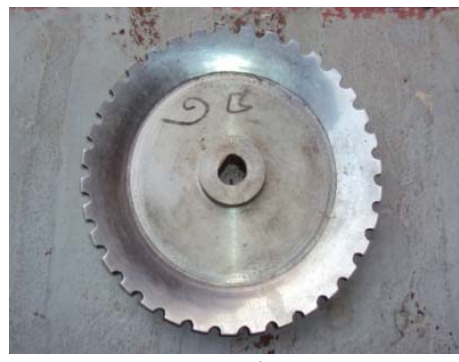

b

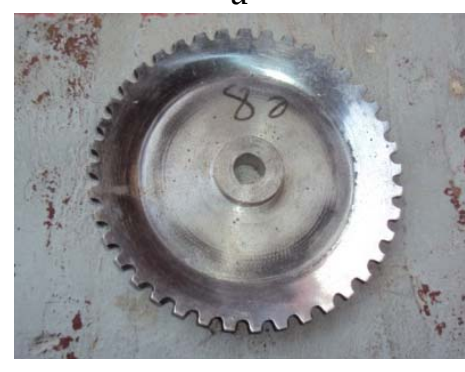

C

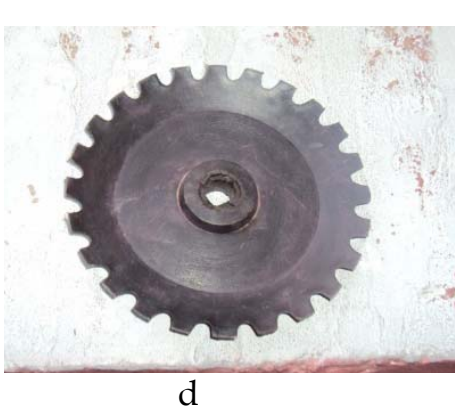

d

Fig. 2. (a) Assembly of inclined plate type seed metering device, (b) Metering device for rice,

(c) Metering device for wheat, (d) Metering device for maize 


\section{Field performance test}

\section{Forward speed}

Forward speed was measured by dividing the distance by time required to travel that distance. Three distances and respective travelling times were recorded. Average value was calculated. Forward speed was calculated by equation (1) (Hunt, 1995).

$$
S=\frac{3.6 \mathrm{D}}{\mathrm{t}}
$$

Where, $\mathrm{S}=$ Forward speed $\left(\mathrm{km} \mathrm{h}^{-1}\right), \mathrm{D}=$ Distance $(\mathrm{m}), \mathrm{t}=$ Time $(\mathrm{s})$

\section{Effective field capacity}

Effective field capacity was determined by equation (2) (Hunt, 1995).

$$
\mathrm{EFC}=\frac{\mathrm{A}}{\mathrm{T}}
$$

Where, $\mathrm{EFC}=$ Effective field capacity $\left(\right.$ ha $\left.\mathrm{h}^{-1}\right), \mathrm{A}=$ Actual operational area (ha), $\mathrm{T}=$ Total operating time $(\mathrm{h})$

\section{Theoretical field capacity}

Theoretical field capacity is the rate of harvesting that would be obtained if the machine was performing its function $100 \%$ of the time at rated forward speed and always covered $100 \%$ of its sowing width. It was calculated by equation (3) (Hunt, 1995).

$$
\mathrm{TFC}=\frac{\mathrm{SW}}{10}
$$

Where, TFC $=$ Theoretical field capacity $\left(\mathrm{ha} \mathrm{h}^{-1}\right), \mathrm{s}=$ Rated forward speed $\left(\mathrm{km} \mathrm{h}^{-1}\right), \mathrm{w}=$ Sowing width $(\mathrm{m})$

\section{Field efficiency}

The field efficiency was determined by equation (4) (Hunt, 1995).

$$
\text { Field efficiency }(\%), \mathrm{FE}=\frac{\mathrm{EFC}}{\mathrm{TFC}} \times 100
$$

\section{Fuel consumption}

Fuel consumption was measured by equation (5) (Hunt, 1995).

$$
\begin{aligned}
& \text { Fuel consumption } \\
& =
\end{aligned}
$$

Where, $\mathrm{F}=$ Amount of fuel (lit), $\mathrm{A}=$ Area covered (ha)

\section{Wheel slippage}

Number of wheel revolution was counted for $10 \mathrm{~m}$ distance coverage for loading and unloading condition. Slip was calculated by equation (6) (Hunt, 1995). 
$S=\frac{N_{l}-N_{u}}{N_{u}} \times 100$

Where, $\mathrm{S}=$ Wheel slippage $(\%), \mathrm{N}_{\mathrm{l}}=$ Number of revolution under loading condition, $\mathrm{N}_{\mathrm{u}}=$ Number of revolution under unloading condition

\section{Seed calibration}

Seed rate was determined through calculation by using equation (7) (Michael and Ojha, 1978).

$$
\mathrm{S}_{\mathrm{d}}=\frac{10 \mathrm{~W}_{2}}{\mathrm{~A}_{\mathrm{m}}}
$$

Where, $S_{d}=$ Seed rate $\left(\mathrm{kg} \mathrm{ha}^{-1}\right), \mathrm{W}_{\mathrm{s}}=$ Total weight of seed $(\mathrm{gm}), \mathrm{A}_{\mathrm{m}}=$ Measured area $\left(\mathrm{m}^{2}\right)$

\section{Seed damage}

Zero Till Drill was operated on a pre-measured $1 \mathrm{~m}$ travel distance and total seeds and damaged seeds were counted. Percent seed damage was calculated by equation (8) (Michael and Ojha, 1978).

$$
\% \text { seed damage }=\frac{\text { No. of total seed }}{\text { No. of damaged seed }} \times 100
$$

\section{Cost analysis}

The annual cost of operation of the zero till drill was computed as the sum of fixed costs and variable costs.

Fixed cost was determined by using the capital consumption method. Capital Consumption (CC) was calculated by equation (9) and (10) (Hunt, 1995).

$\mathrm{CC}=(\mathrm{P}-\mathrm{S}) \mathrm{CRF}+\mathrm{Si}$

$$
C R F=\frac{I(1+1)^{\mathrm{L}}}{(1+1)^{\mathrm{L}}-1}
$$

Where, $\mathrm{P}=$ Purchase price, $\mathrm{S}=$ Salvage value, $\mathrm{CRF}=$ Capital recovery factor, $\mathrm{i}=$ Interest rate, $\mathrm{L}=$ Number of years

Variable cost (VC) was calculated by adding all cost elements as shown in equation (11). $\mathrm{VC}=\mathrm{F}_{\mathrm{c}}+\mathrm{OL}_{\mathrm{c}}+\mathrm{RM}_{\mathrm{c}}+\mathrm{I}_{\mathrm{c}}+\mathrm{SF}_{\mathrm{c}}+\mathrm{WC}$

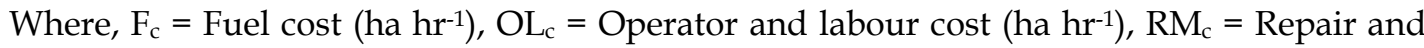
maintenance cost $\left(\right.$ ha hr-1), $I_{c}=$ Irrigation cost $\left(\right.$ ha hr-1), $\mathrm{SF}_{\mathrm{c}}=$ Seed and fertilizer cost $\left(\mathrm{ha} \mathrm{hr} \mathrm{h}^{-1}\right)$, $\mathrm{WC}_{\mathrm{c}}=$ Weed control cost $($ ha hr-1) 


\section{RESULTS AND DISCUSSION}

\section{Field performance}

Field performance of power tiller operated zero till drill is shown in Table 2.

Table 2. Field performance of power tiller operated zero till drill

\begin{tabular}{lc}
\hline \multicolumn{1}{c|}{ Operation } & Value \\
\hline Forward speed $\left(\mathrm{km} \mathrm{hr}^{-1}\right)$ & 2.39 \\
Effective field capacity $\left(\mathrm{ha} \mathrm{hr}^{-1}\right)$ & 0.115 \\
Field efficiency (\%) & 80.19 \\
Fuel consumption (lit hr-1) & 1.33 \\
Wheel slippage (\%) & 10 \\
\hline
\end{tabular}

\section{Comparison of planting performance}

The comparison of planting performance is shown in Fig. 3.

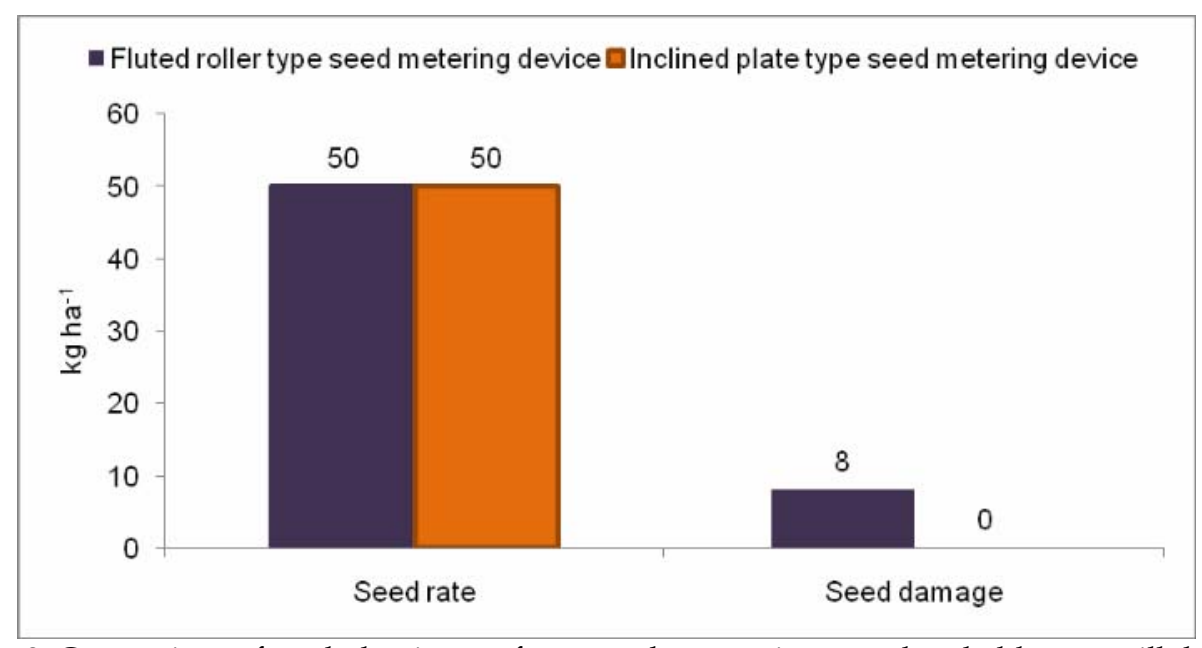

Fig. 3. Comparison of seed planting performance between improved and older zero till drills

It was found that seed rate was identical in both of the zero till drills. But seed damage was found in the old zero till drill, which was not found in the improved zero till drill. The reason behind this was fluted roller type metering device caused some seed damage, but inclined plate type metering device caused no damage to the seeds.

\section{Comparison of planting cost}

The comparison of planting cost is shown in Fig. 4.

It was found that planting cost of the improved zero till drill was lower than the older one. It was due to the elimination of seed damage by the improved seed metering device. 


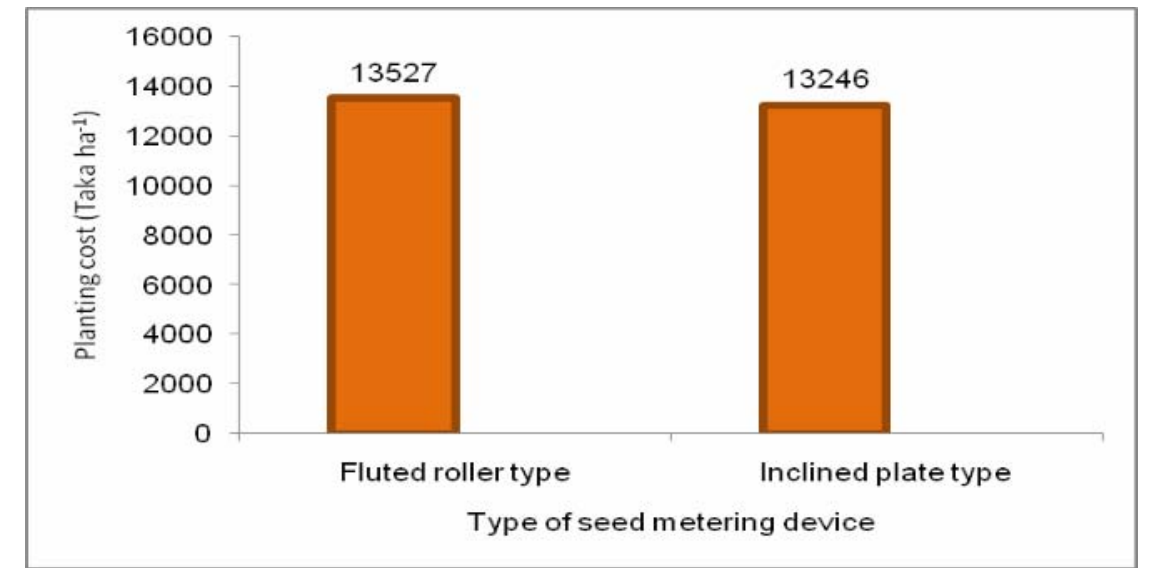

Fig. 4. Comparison of seed planting cost between improved and older zero till drills

\section{CONCLUSION}

The present study was conducted to improve the seed metering system of power tiller operated zero till drill by replacing the fluted roller type metering device with inclined plate type metering device. The study showed superiority of the improved seed metering device over the older version. No seed damage was found during operation and planting cost decreased by 280 Taka ha- $^{-1}$. Therefore this improvement was proven successful.

\section{REFERENCES}

Carter, M. R. 1992. Influence of reduced tillage systems on organic matter, microbial biomass, macroaggregate distribution and structural stability of the surface soil in humid climate. Soil Till. Res., 23: $361-372$.

Dabbaghi, A., Massah, J. and Alizadeh, M. 2010. Effect of rotational speed and length of the fluted-roll seed metering device on the performance of pre-germinated paddy seeder unit. International Journal of Natural and Engineering Sciences, 4(3): 07-11

Figueroa, B. and Morales, F. J. 1992. Manual de producción de cultivos con labranza de conservación. CREZAS. CP. SLP, México, p. 272.

Hunt, D. 1995. Farm power and machinery management- $9^{\text {th }}$ edn. Iowa State University Press, Ames, Iowa, USA.

Johnston, A. M., Clayton, G. W., Wall, P. C. and Sayre, K. D. 2002. Sustainable cropping systems for semiarid regions. Paper Presented at the International Conference on Environmentally Sustainable Agriculture for Dry Areas for the 2nd Millennium, September 15-19, 2002, Shijiazhuang, Hebei Province, P.R.C.

Lampkin, N. 1998. Organic Farming. Farming Press, EEUU, p. 724.

Lichter, K., Govaerts, B., Six, J., Sayre, K. D., Deckers, J. and Dendooven, L. 2008. Aggregation and C and $\mathrm{N}$ contents of soil organic matter fractions in the permanent raised-bed planting system in the Highlands of Central Mexico. Plant Soil., 305: 237-252. 
Michael, A. M. and Ojha, T. P. 1978. Principle of agriculture engineering, Vol. 1. Jain Brothers (New Delhi), 873, East Park Road, New Delhi, India.

Phillips, S. H. and Young, H. M. 1973. No-Tillage Farming. Reiman Associates, Milwaukee, Wisconsin, pp. 224.

Shaver, T. M., Peterson, G. A., Ahuja, L. R., Westfall, D. G., Sherrod, L. A. and Dunn, G. 2002. Surface soil properties after twelve years of dryland no-till management. Soil Sci. Soc. Am. J., 66: 1292-1303.

Wall, P. C. 2006. Facilitating the widespread adoption of conservation agriculture and other resource conserving technologies (RCT's): some difficult issues. Science week Extended Abstracts. CIMMYT Headquarters, El Batán, México, 23-27 January 2006, pp. 61-64. 